\title{
Analysis of the frequency and degree of temporomandibular disorder in patients with head and neck cancer undergoing radiotherapy
}

\author{
Análise da frequência e grau de disfunção temporomandibular em \\ pacientes com câncer de cabeça e pescoço submetidos à radioterapia
}

\author{
Douglas Roberto Pegoraro ${ }^{[a]}$, Barbara Zanchet ${ }^{[b]}$, Caroline de Oliveira Guariente ${ }^{[a]}$, \\ Josemara de Paula Rocha ${ }^{[c]}$, Juliana Secchi Batista ${ }^{[a] *}$ \\ [a] Universidade de Passo Fundo (UFP), Passo Fundo, RS, Brazil \\ [b] Universidade Comunitária da Região de Chapecó (Unochapecó), Chapecó, SC, Brazil \\ [c] Pontifícia Universidade Católica do Rio Grande do Sul (PUCRS), Brazil
}

\begin{abstract}
Introduction: Head and neck cancer is responsible for an increasing incidence of primary malignant neoplasm cases worldwide. Radiotherapy is one of the treatments of choice for this type of cancer, but it can cause adverse effects, such as temporomandibular disorder. The objective of this study was to characterize the degree and frequency of temporomandibular disorder in patients with head and neck cancer undergoing radiotherapy. Method: This research was quantitative, descriptive and exploratory. The sample consisted of 22 patients that answered assessment questions and the Helkimo anamnestic questionnaire, modified by Fonseca (1992). The data were collected from May to October 2014, and statistically analyzed using the Chi-square test, with a significance level of $\mathrm{p} \leq 0.05$. Results: Of the 22 patients, $86.4 \%$ were male, with a mean age of $58.86 \pm 9.41$ years. Temporomandibular disorder was present in $31.8 \%$ of the subjects, based on the assessment prior to radiotherapy, and in $59.1 \%$ in the post-treatment assessment. Among
\end{abstract}

\footnotetext{
*DRP: Grad, e-mail: douglaspegfisioterapia@gmail.com BZ: MSc student, e-mail: bzanchet@unochapeco.edu.br COG: Grad, e-mail: cguarienti@hotmail.com JPR: PhD, e-mail: josemara.rocha@hotmail.com JSB: MSc, e-mail: ju.secchi@hotmail.com
} 
all questions, the most frequent was "Do you use only one side of the mouth to chew?" with $22.7 \%$ "yes" answers, both at the first assessment and at the post treatment. Conclusion: According to the results of this study, temporomandibular disorder is a disease that is present with a high prevalence in people diagnosed with head and neck cancer undergoing radiotherapy.

Keywords: Radiotherapy. Temporomandibular Joint Dysfunction Syndrome. Head and Neck Neoplasms.

\section{Resumo}

Introdução: O câncer de cabeça e pescoço é responsável por uma crescente incidência de neoplasias malignas primárias no mundo. A radioterapia é um dos tratamentos de escolha para este tipo de câncer, porém pode causar efeitos adversos, como a Disfunção Temporomandibular. O objetivo deste estudo foi caracterizar o grau e a frequência da Disfunção Temporomandibular em pacientes com câncer de cabeça e pescoço submetidos à radioterapia. Método: A pesquisa é quantitativa, descritiva e exploratória. A amostra foi composta por 22 pacientes que responderam a uma ficha de avaliação e ao questionário de anamnese de Helkimo modificado por Fonseca (1992). Os dados foram coletados entre maio e outubro de 2014 e analisados estatisticamente através do teste de Qui-Quadrado, com um nível de significância de $p \leq 0$,05. Resultados: Dos 22 pacientes, 86,4\% eram do sexo masculino, com idade média $58.86 \pm 9.41$ anos. A Disfunção Temporomandibular esteve presente em 31,8\% dos indivíduos na avaliação prévia à radioterapia, e em 59,1\% na avaliação pós-tratamento. Entre todas as questões, a que mais apresentou incidência foi "Você usa apenas um lado da boca para mastigar?", com 22,7\% respostas "sim", tanto na avaliação inicial como na final. Conclusão: De acordo com os resultados do presente estudo, a Disfunção Temporomandibular é uma patologia presente e com grande prevalência em pessoas que foram diagnosticadas com câncer de cabeça e pescoço que foram submetidas ao tratamento radioterápico.

Palavras-chave: Radioterapia. Síndrome da Disfunção da Articulação Temporomandibular. Neoplasias de Cabeça e Pescoço.

\section{Introduction}

Head and neck cancer (HNC) has an incidence of 900,000 cases per year worldwide, and corresponds to the sixth leading cause of death. In Europe, $98 \%$ of patients are older than 40 years $(1,2)$. Smoking and alcohol are well established risk factors for this type of cancer. Although this neoplasia more commonly affects male patients, there has been a noticeable increase in the incidence among women in recent years, which reflects changes in smoking and alcohol consumption habits (3).

The treatment of choice for these neoplasias is surgery, with or without radiotherapy (RT), which subjects patients to doses of ionizing radiation in areas that include various facial structures. The side effects of RT in the treatment of patients with HNC significantly interfere in the quality of life of the patients. Effects in the head and neck include: mucositis, dermatitis, dry mouth, hypogeusia, osteoradionecrosis, fibrosis and trismus $(4,5)$, which can cause functional changes in the temporomandibular joint (TMJ), resulting in a dysfunction of this joint, namely temporomandibular disorder (TMD).

The TMJ is a complex joint system of the human body, consisting of the condyle, mandibular fossa and articular tubercle of the temporal bone (6). According to the Term of the First Consensus on Temporomandibular Disorders and Orofacial Pain (7), TMD is defined as a group of disorders involving the masticatory muscles, the TMJ and associated structures. Decreased function of this joint causes numerous difficulties for the subjects, and, consequently, impairs their quality of life (5).

Given the high prevalence of the disease, the complications that RT can cause, and the importance of knowledge on the development of TMD in the population affected by head and neck tumors, the aim of this study was to analyze the frequency and degree of TMD in patients with head and neck cancer undergoing RT, in order to contribute to the promotion, knowledge and interest of the health-related problems in the population with cancer. 


\section{Method}

Study design and sample selection

The study was quantitative, descriptive, exploratoryand was approved by the Ethics Committee of the University of Passo Fundo, under protocol number 664157/2014.

The subjects' participation was subject to the following criteria: having a confirmed diagnosis of cancer in the oral mucosa, lips, gums, hard palate, tongue, floor of the mouth or retromolar trigone; pharynx, which includes: oropharynx (base of the tongue and soft palate), the nasopharynx and the hypopharynx (pyriform sinus, pharyngeal wall and post-cricoid area); nasal cavity and paranasal sinuses; glottis and supraglottic larynx and salivary glands. The exclusion criteria were: subjects with intellectual disability preventing their response to the questionnaire, those who had not completed RT, and those who refused to participate. Study participants were under treatment at the RT department of a large hospital in Rio Grande do Sul, and were selected through preliminary analysis of the histopathological examination, from May to October 2014.

Procedures and data collection

First, the research objectives were explained to each participant, and the assessment process began after acceptance and signature of the terms of free and informed consent form (ICF). Initially an assessment form was completed, containing socio-demographic data and information about RT. It contained identification data, type of tumor, treatments performed, education, weight, height, sex, comorbidities, medication use, problems with ATM, use of dentures, problems with loss of teeth, previous physical therapy treatments, smoking habits, radiation dose, number of sessions, use of nasogastric/enteral tubes.

The Helkimo questionnaire, modified by Fonseca $(8,9)$, was applied latter, and consisted of 10 (ten) objective questions and the TMD grading scale. It has simple and direct questions, and the subject must check one of three alternatives ("yes," "no", and "sometimes"). For each answer, there is an associated value, used for the final analysis of TMD in the individual. The subject with a score between 0 and 3 points is classified as "no TMD"; between 4 and 8 points, "mild TMD"; between 9 and 14 points, "moderate TMD"; and 15 or more points, "severe TMD".

The study was conducted between the first and the fifth day of treatment (baseline assessment), when the subject completed the questionnaire and the assessment form, and after the last application of RT (final assessment), when the patient answered the questionnaire only, in order to assess the disease after the end of treatment, and to compare the data at baseline and at the end of the applications.

\section{Data analysis}

The collected data were organized with the support of spreadsheets, and structured in Excel 2007. For statistical and descriptive analysis, using SPSS version 15 , the chi-square test was used, with a significance level of $\mathrm{p} \leq 0.05$.

\section{Results}

Twenty-six patients were selected for the study; 22 completed the research. Two subjects were excluded due to death during treatment, one because of indefinite suspension of treatment, and one for being unable to answer the questions (Figure 1).

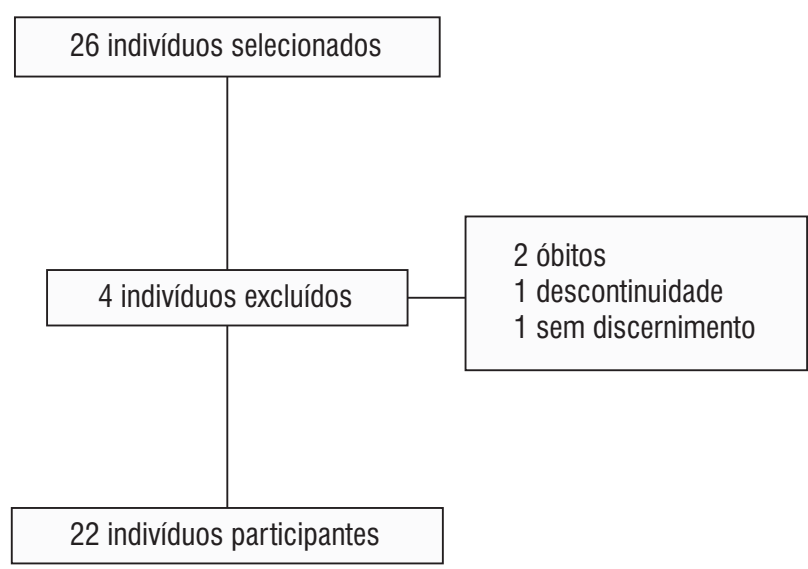

Source: Data collection 2014, the authors.

Figure 1- Exclusion process of the selected subjects

Among the patients, $19(86.4 \%)$ were male and three $(13.6 \%)$ were female, with a mean age of 58.86 $( \pm 9.41)$ years. Thirteen $(59.1 \%)$ of the subjects answered that they used some kind of medication. Fifteen (68.2\%) had incomplete primary education.

The most frequent tumor histology was squamous cell carcinoma, in 20 (90.9\%) assessments. The most frequent sites affected by cancer were: larynx (6, $27.3 \%)$, oropharynx $(4,18.2 \%)$, oral cavity $(3,13.6 \%)$ 
and parotid gland $(2,9.1 \%)$. In addition, 7 (31.8\%) had tumors in other sites. When asked about the history of cancer in the family, 12 (54.5\%) had some kind of disease in close relatives (parents), while ten (45.5\%) answered negatively.

One $(4.5 \%)$ patient admitted having had some sort of TMJ-related problem, and 21 (95.5\%) stated that they had never noticed any problems. When asked about the use of dentures, three (13.6\%) patients stated that they did not use them, whereas 19 (86.4\%) used some type of denture. Ten patients (45.5\%) stated that they had already had some kind of problem related to tooth loss, while 12 (54.5\%) answered negatively (Table 1).

Regarding smoking, 18 (81.1\%) of the respondents were smokers; four $(18.2 \%)$ stated that they did not smoke. Among smokers, nine (50\%) reported smoking more than 30 cigarettes a day; eight (44.4\%) reported smoking between ten and 29 cigarettes a day, and one (5.6\%) reported smoking less than ten cigarettes a day. The mean number of cigarettes smoked per day was 43 ( \pm 31.52$)$. Sixteen (88.9\%) smokers had the habit for 30 years, and two (11.1\%) had been smoking between ten and 29 years. The mean time since they started smoking was 36.67 ( \pm 8.57 ) years.

Table 2 shows the analysis of the TMD questionnaire at the beginning and at the end of treatment. With regard to the question, "Do you notice any noise in the TMJ?" in the initial assessment, two patients (9.1\%) had bilateral symptoms, and one point was added to the total score (according to the guidelines for interpretation of the questionnaire). In the final assessment, two patients (9.1\%) reported bilateral symptoms when asked, "Do you have pain in the ear or close to it?", and one $(4.5 \%)$ reported individual bilateral symptoms when asked, "Do you notice any sound in the TMJ?". In both cases, one point was also added to the total score.
When the results of the questionnaire were evaluated, it was noticed that 15 (68.2\%) patients did not have TMD at the beginning of treatment, while seven (31.8\%) had a mild degree of TMD. The mean baseline score of the questionnaire was $2.68( \pm 2.21)$. Among all the questions, the one with the highest incidence was, "Do you use only one side of the mouth to chew?", with five (22.7\%) "yes" answers, four (18.2\%) "sometimes" answers, and 13 (59.1\%) "no" answers.

In the final assessment, nine (40.9\%) selected patients remained without TMD. However, 13 (59.1\%) had a mild degree of TMD. The mean score in the final assessment was $3.91( \pm 2.20)$. The question, "Do you use only one side of the mouth to chew?" remained the most common, with five (22.7\%) "yes" answers, five (22.7\%) "sometimes" answers, and 12 (54.5 \%) "no" answers. The questions "Do you feel discomfort or muscle pain when chewing?", and, "Do you have pain in the ear or close to it?" also had five (22.7\%) "yes" answers.

A significant result $(\mathrm{p}=0.028)$ was observed, relating the initial TMD score with the final TMD score (Table 3).

Table 1 - Sample characteristics

\begin{tabular}{lcccc}
\hline Variables & \multicolumn{2}{c}{ Yes } & \multicolumn{2}{c}{ No } \\
\cline { 2 - 5 } & $\mathbf{n}$ & $\%$ & $\mathbf{n}$ & $\%$ \\
Medication use & 13 & 59.1 & 9 & 40.9 \\
Family history of & 12 & 54.5 & 10 & 45.5 \\
cancer & 18 & 81.8 & 4 & 18.2 \\
Smoking & 10 & 45.5 & 12 & 54.5 \\
Tooth loss & 19 & 86.4 & 3 & 13.6 \\
Use of denture & 1 & 4.5 & 21 & 95.5 \\
TMJ problems & & & & \\
\hline
\end{tabular}

Note: Source: Data collection 2014, the authors

Table 2 - Analysis of the questionnaire to assess the TMD at baseline and at the end of treatment

(To be continued)

\begin{tabular}{|c|c|c|c|c|c|c|c|c|c|c|c|c|}
\hline \multirow{3}{*}{ Variables } & \multicolumn{6}{|c|}{ Baseline } & \multicolumn{6}{|c|}{ End } \\
\hline & \multicolumn{2}{|c|}{ Yes } & \multicolumn{2}{|c|}{ No } & \multicolumn{2}{|c|}{ Sometimes } & \multicolumn{2}{|c|}{ Yes } & \multicolumn{2}{|c|}{ No } & \multicolumn{2}{|c|}{ Sometimes } \\
\hline & $\mathrm{n}$ & $\%$ & $\mathbf{N}$ & $\%$ & $\mathrm{n}$ & $\%$ & $\mathbf{n}$ & $\%$ & $\mathrm{n}$ & $\%$ & $\mathrm{n}$ & $\%$ \\
\hline $\begin{array}{l}\text { Difficulty opening the } \\
\text { mouth }\end{array}$ & 2 & 9.1 & 19 & 84.6 & 1 & 4.5 & 4 & 18.2 & 14 & 63.6 & 4 & 18.2 \\
\hline $\begin{array}{l}\text { Difficulty moving the } \\
\text { jaw sideways }\end{array}$ & 2 & 9.1 & 20 & 90.9 & 0 & 0 & 2 & 9.1 & 16 & 72.7 & 4 & 18.2 \\
\hline $\begin{array}{l}\text { Discomfort or muscle } \\
\text { pain when chewing }\end{array}$ & 1 & 4.5 & 19 & 84.6 & 2 & 9.1 & 5 & 22.7 & 15 & 68.2 & 2 & 9.1 \\
\hline
\end{tabular}


Table 2 - Analysis of the questionnaire to assess the TMD at baseline and at the end of treatment

(Conclusion)

\begin{tabular}{|c|c|c|c|c|c|c|c|c|c|c|c|c|}
\hline \multirow{3}{*}{$\begin{array}{c}\text { Variables } \\
\text { Frequent headaches }\end{array}$} & \multicolumn{6}{|c|}{ Baseline } & \multicolumn{6}{|c|}{ End } \\
\hline & \multicolumn{2}{|c|}{ Yes } & \multicolumn{2}{|c|}{ No } & \multicolumn{2}{|c|}{ Sometimes } & \multicolumn{2}{|c|}{ Yes } & \multicolumn{2}{|c|}{ No } & \multicolumn{2}{|c|}{ Sometimes } \\
\hline & 2 & 9.1 & 1 & 4.5 & 19 & 84.6 & 1 & 4.5 & 18 & 81.8 & 3 & 13.6 \\
\hline $\begin{array}{l}\text { Pain in the neck and/or } \\
\text { shoulders }\end{array}$ & 0 & 0 & 17 & 77.3 & 5 & 22.7 & 2 & 9.1 & 16 & 72.7 & 4 & 18.2 \\
\hline $\begin{array}{l}\text { Earache or pain close } \\
\text { to the ear }\end{array}$ & 3 & 13.6 & 14 & 63.7 & 5 & 22.7 & 5 & 22.7 & 14 & 63.7 & 3 & 13.6 \\
\hline Any sound in the TMJ & 1 & 4.5 & 18 & 81.8 & 3 & 13.6 & 1 & 4.5 & 19 & 86.4 & 2 & 9.1 \\
\hline Abnormal bite & 1 & 4.5 & 18 & 81.8 & 3 & 13.6 & 0 & 0 & 20 & 90.9 & 2 & 9.1 \\
\hline $\begin{array}{l}\text { Using only one side of } \\
\text { the mouth to chew }\end{array}$ & 5 & 22.7 & 13 & 59.1 & 4 & 18.2 & 5 & 22.7 & 12 & 54.5 & 5 & 22.7 \\
\hline $\begin{array}{l}\text { Pain in the face when } \\
\text { awake }\end{array}$ & 0 & 0 & 22 & 100.0 & 0 & 0 & 1 & 4.5 & 21 & 95.5 & 0 & 0 \\
\hline
\end{tabular}

Note: Source: Data collection 2014, the authors

Table 3 - Analysis of the degree and frequency of baseline TMD and TMD at the end of the treatment

\begin{tabular}{lcc|cc|c}
\hline Variables & \multicolumn{1}{c|}{ Baeline TMD } & \multicolumn{2}{|c|}{$\begin{array}{c}\text { TMD at the } \\
\text { end }\end{array}$} & p* \\
\cline { 2 - 5 } No TMD & $\mathrm{N}$ & $\%$ & $\mathrm{n}$ & $\%$ & \\
\cline { 2 - 5 } Mild TMD & 7 & 68.2 & 9 & 40.9 & 0.028 \\
\hline
\end{tabular}

${ }^{\star}$ Chi-square test $p \leq 0.05$

Note: Source: Data collection 2014, the authors

\section{Discussion}

This study showed a higher incidence of HNC in males, which corroborates the study by Alvarenga et al. (3), which showed a percentage of $86 \%$ in men. Sawada et al. (10) showed a prevalence of $78 \%$ in men, in a sample of 32 individuals. Hadjieva et al. (11) had a sample with $84 \%$ males.

The most frequent cell histology was squamous cell carcinoma, as shown in several studies $(12,14$, 19). The vast majority (over $90 \%$ ) of HNC cases is squamous cell carcinoma (13). The larynx was the region most frequently affected by tumors in the present study sample, similar to the results of another study, in which laryngeal cancer accounted for $53.5 \%$ of the sample (15). However, in the study by Santos et al. (16), there was a higher incidence in the oropharynx, with the larynx at fourth place in incidence.

Smoking was a habit reported by $81.1 \%$ of the patients. Several studies $(17,18)$ also had high percentages of smokers among patients with HNC, in accordance with the results of the present study. Smoking is one of the main risk factors for the development of HNC, along with alcohol consumption. In addition, the continuity of smoking after treatment increases the risk of disease recurrence $(19,20)$.

In the baseline assessment of TMD, 31.8\% of patients had a mild degree of TMD. In the final assessment, this percentage increased to $59.1 \%$. In a study that evaluated mouth opening in 26 subjects, 30 days before RT and 90 days after the end of treatment, there was no statistically significant reduction in mouth opening, but the study showed that 73.07 $\%$ of the individuals had limited pre-radiotherapy mouth opening (21).

A study measured the maximum mouth opening of 143 patients with HNC before beginning treatment and at zero, six and 12 months after the end of treatment. In all individuals, the maximum mouth opening diminished. Patients undergoing surgery only partially recovered mouth opening after six and 12 months, but the subjects undergoing RT did not recover it (33). In another recent study, oral pain was statistically significant in patients under RT (23). Trismus is also frequently present before RT in patients with HNC: about $75 \%$ of patients have symptoms (22). 
Dijkstra et al. (24) found a percentage of 78\% of cancer-related trismus in their study and, of these, $90 \%$ had undergone RT. In another study (25), the authors state that RT involving the TMJ structures reduces the patients' mouth opening by $18 \%$. In the present study, statistical significance was found between the baseline TMD score and the score at the end of treatment. Studies have been conducted showing that RT is a determining factor for the development of TMD, especially trismus, corroborating the results of this study $(26,27)$.

Wang et al. (28) followed 17 subjects post-radiotherapy and found that after the first month of treatment, the patients' mouth opening decreased dramatically. A recent study found that about half of those treated with RT developed some kind of oral dysfunction, in addition to reporting problems opening the mouth, eating and drinking (29). However, the literature shows that the process of oral functional limitation occurs months after the end of RT (30).

There was also a higher incidence of the question, "Do you often have headaches?", in patients receiving moderate doses of radiation. In a study analyzing the adverse effects of RT, the author points out that patients undergoing RT can have headaches associated with difficulty opening the mouth (31). Silva et al. (32) state that the duration and severity of the side effects of RT in the oral cavity depend on the doses and the areas where the radiation was administered. Another study found that the side effects of RT are also dependent on the total dose and its fractioning (4).

\section{Conclusion}

According to the results of this study, it can be concluded that TMD is a highly prevalent disease in subjects diagnosed with HNC, undergoing RT. Mild TMD was the most common in the subjects, but further studies are needed to better characterize this disease in patients with $\mathrm{HNC}$, as well as its possible prevention and treatment.

\section{References}

1. Ruiz MT, Pavarino-Bertelli E, Maniglia JV, Ruback MJC, Goloni-Bertollo EM. Epidemiologia e biomarcadores em câncer de cabeça e pescoço. Arq Ciênc Saúde. 2006; 13(1):34-8.
2. Silveira A, Gonçalves J, Sequeira T, Ribeiro C, Lopes C, Monteiro E, et al. Head and Neck Cancer: Health Related Quality of Life Assessment considering clinical and epidemiological perspectives. Rev Bras Epidemiol. 2012; 15(1):38-48.

3. Alvarenga LM, Ruiz MT, Pavarino-Bertelli EC, Ruback MJC, Maniglia JC, Goloni-Bertollo EM. Avaliação epidemiológica de pacientes com câncer de cabeça e pescoço em um hospital universitário do noroeste do estado de São Paulo. Rev Bras Otorrinolaringol. 2008; 74(1):68-73.

4. Jham BC, Freire ARS. Complicações bucais da radioterapia em cabeça e pescoço. Rev Bras Otorrinolaringol. 2006; 72(5):704-8.

5. Bragante KC, Nascimento DM, Motta NW. Avaliação dos efeitos agudos da radioterapia sobre os movimentos mandibulares de pacientes com câncer de cabeça e pescoço. Rev Bras Fisioterapia. 2011; 16(2):141-7.

6. Stechman Neto J, Floriani A, Carrilho E, Milani PAP. Articulação temporomandibular em pacientes geriátricos. J Bras Oclusão ATM Dor Orofac. 2002; 2(8):345-50.

7. Carrara SV, Conti PCR, Barbosa JS. Termo do $1^{\circ}$ Consenso em Disfunção Temporomandibular e Dor Orofacial. Dental Press J Orthod. 2010; 15(3):114-20.

8. Fonseca DM. Disfunção Temporomandibular (DTM): elaboração de um índice anamnésico [Dissertação]. Bauru: Faculdade de Odontologia de Bauru; 1992.

9. Fonseca DM, Bonfate G, Valle AL, Freitas SFT. Diagnóstico pela anamnese da disfunção craniomandibular. Rev Gaucha Odontol. 1994; 42(1):23-8.

10. Sawada NO, Dias AM, Zago MMF. O efeito da radioterapia sobre a qualidade de vida dos pacientes com câncer de cabeça e pescoço. Rev Bras Cancerol. 2006; 52(4):323-9.

11. Hadjieva T, Cavallin-Ståhl E, Linden M, Tiberg F. Treatment of oral mucositis pain following radiation therapy for head-and-neck cancer using a bioadhesive barrier-forming lipid solution. Support Care Cancer. 2014; 22(6):1557-62.

12. Antunes AA, Antunes AP. Estudo retrospectivo e revisão de literatura dos tumores dos lábios: experiência de 28 anos. Rev Bras Cancerol. 2004; 50(4):295-300. 
13. Galbiatti ALS, Padovani-Junior JA, Maníglia JV, Rodrigues CDS, Pavarino EC, Goloni-Bertollo EM. Câncer de cabeça e pescoço: causas, prevenção e tratamento. Braz J Otorhinolarungol. 2013; 79(2):239-47.

14. Schöder H. Head and neck cancer. In: Strauss HW, Mariani G, Volterrani D, Larson SM (eds). Nuclear oncology: pathophysiology and clinical applications. New York: Springer; 2013 . p. 269-95.

15. Almeida AA, Bandeira CM, Gonçalves AJ, Araújo AJ. Dependência nicotínica e perfil tabágico em pacientes com câncer de cabeça e pescoço. J Bras Pneumol. 2014; 40(3):286-93.

16. Santos RCS, Dias RS, Giordani AJ, Segreto RA, Segreto HRC. Mucosite em pacientes portadores de câncer de cabeça e pescoço submetidos à radioquimioterapia. Rev Esc Enferm USP. 2011; 45(6): 1338-44.

17. Zhou J, Michaud DS, Langevin SM, McClean MD, Eliot M, Kelsey KT. Smokeless tobacco and risk of head and neck cancer: Evidence from a casecontrol study in New England. Int J Cancer. 2013; 132(8):1911-7.

18. Mashberg A, Boffetta P, Winkelman R, Garfinkel W. Tobacco smoking, alcohol drinking, and cancer of oral cavity and orophariynx among US veterans. Cancer. 1993; 72(4):1369-75.

19. Casati MFM, Vasconcelos JA, Vergnhanini GS, Contreiro PF, Graça TB, Kanda JL, et al. Epidemiologia do câncer de cabeça e pescoço no Brasil: estudo transversal de base populacional. Rev Bras Cir Cabeça Pescoço. 2012; 41(4):186-91.

20. Maasland DHE, Brandt PAVD, Kremer B, Goldbohm A, Schouten LJ. Alcohol consumption, cigarette smoking and the risk of subtypes of head-neck cancer: results from the Netherlands Cohort Study. BMC Cancer. 2014; 14:187.

21. Ribas PF, Savioli C, André M, Dias RB. Avaliação da abertura bucal em pacientes submetidos à radioterapia de cabeça e pescoço. Odonto. 2011;19(38):99-104.
22. Almeida FCS, Vaccarezza GF, Cazal C, Benedethe APF, Pinto Jr DS, Tavares MR, et al. Avaliação odontológica de pacientes com câncer de boca pré e pós tratamento oncológico - uma proposta de protocolo. Pesq Bras Odontoped Clin Integr. 2004; 4(1):25-31.

23. Nicolatou-Galitis O, Kouloulias V, Sotiropoulou-Lountou A, Dardoufas K, Polychronopoulou A, Athanassiadou A, et al. Oral mucositis, pain and xerostomia in 135 head and neck cancer patients receiving radiotherapy with or without chemotherapy. The Open Cancer J. 2011;4: 7-17.

24. Dijkstra PU, Sterken MW, Pater R, Spijkervet FKL, Roodenburg JLN. Exercise therapy for trismus in head and neck cancer. Oral Oncol. 2007;43:389-94.

25. Dijkstra PU, Kalk WW, Roodenburg JL. Trismus in head and neck oncology: a systematic review. Oral Oncology. 2004; 40(9):879-89.

26. Rolim AEH, Costa LJ, Ramalho LMP. Repercussões da radioterapia na região orofacial e seu tratamento. Radiol Bras. 2011; 44(6):388-95.

27. Spanemberg JC; Cardoso JA; Pinto Filho JM. Prevenção e administração das complicações bucais do tratamento oncológico de cabeça e pescoço. Arch Oral Res. 2012; 8(3):231-9.

28. Wang CJ, Huang EY, Hsu HC, Chen HC, Fang FM, Hsiung $\mathrm{CY}$. The degree and time-course assessment of radiation-induced trismus occurring after radiotherapy for nasopharyngeal cancer. The Laryngoscope. 2005; 115(8):1458-60.

29. Weber C, Dommerich S, Hans WP, Burkhard K. Limited mouth opening after primary therapy of head and neck cancer. Oral Maxillofac Surg. 2010; 14(3):169-73.

30. Vissink A, Jansma J, Spijkervet FK, Burlage FR, Coppes RP. Oral sequelae of head and neck radiotherapy. Crit Rev Oral Biol Med. 2003; 14:199-212.

31. Basu T, Laskar SG, Gupta T, Budrukkar A, Murthy V, Agarwal JP. Toxicity with radiotherapy for oral cancers and its management: A practical approach. J Can Res Ther 2012; 8 (Suppl 1):72-84.

32. Silva AIV, Galante C, Manzi FR. Efeito da radiação ionizante sobre o paladar em pacientes submetidos a radioterapia para a região da cabeça e pescoço. Radiol Bras. 2011; 44(5):297-300. 
33. Wetzels JWGH, Merkx MAW, De Haan AFJ, Koole R, Speksnijder CM. Maximum mouth opening and trismus in 143 patients treated for oral cancer: A 1-year prospective study. Head Neck. 2014; 36(12):1754-62.

Received: $12 / 08 / 2014$

Recebido: 08/12/2014

Approved: 10/08/2015

Aprovado: 08/10/2015 